\section{Adoption of International Financial Reporting Standards [IFRSS] and their Impact on Loan Terms: Kosovo Gase}

\section{Teaching Assistant Edona PERJUCl, Ph. D. Candidate,} University of Prishtina, Faculty of Economics, e-mail: edonaperjuci@hotmail.com

Univ. Prof. Hysen ISMAJLI, University of Pristina, Faculty of Economics, Kosovo, e-mail: hysen.ismajil@gmail.com

Ardiana BUNJAKU, Ph. D. Candidate, Executive Director of Society of Certified Accountants and Auditors of Kosovo, e-mail: ardianabunjaku@hotmail.com

\section{ABSTRAGT}

As part of the major international developments on financial reporting and auditing, the International Financial Reporting Standards (IFRS), which are now applied in many countries around the world, are creating an international harmonization and a common language for financial reporting and accounting between firms that apply and report in accordance to these standards. This paper empirically tests whether adoption of IFRS in developing and transitional Kosovo, has impact on bank's loan terms and conditions for companies that are mandatory adopters of IFRSs. To test the hypothesis, the authors analyzed the opinions of the banking sector and of companies that are mandatory adopters of IFRSs in Kosovo. The research results suggest that the adoption of IFRSs in Kosovo has impact on interest rates offered by banks to mandatory adopters, as well as on non-financial loan terms such as: loan time limits, mortgage requirements, lower administrative costs and renegotiating loan terms. Mandatory IFRS adopters have a better loan rating compared to other companies in Kosovo and the percentage of non-performing loans is lower for mandatory IFRS adopters in Kosovo. Based on this research, the aim is to demonstrate to policy makers and other stakeholders that only the mere implementation of high quality financial reporting standards, such as IFRSs, is not sufficient to improve the quality of accounting and financial reporting in Kosovo, especially since there are no institutional mechanisms to empower the implementation of IFRSs. For companies in Kosovo receiving better loan terms from banks can be an incentive to improve their financial reporting systems, but the focus is also on other benefits that should be considered as well.

Keywords: IFRS, financial statements, cost of borrowings, loan terms, disclosures, transparency, accountability

\section{JEL Classification: M41, M42}

To cite this article:

Perjuci, E., Ismajli, H., Bunjaku, A. (2019), Adoption of International Financial Reporting Standards (IFRSs) and their Impact on Loan Terms: Kosovo Case, Audit Financiar, vol. XVII, no. $1(153) / 2019$, pp. 124-133,

DOI: 10.20869/AUDITF/2019/153/005

To link this article:

http://dx.doi.org/10.20869/AUDITF/2019/153/005

Received: 15.10 .2018

Revised: 06.11 .2018

Accepted: 01.12.2018 


\section{Introduction}

The adoption of International Financial Reporting Standards (IFRSs) in many countries of the world is a momentum in the development of the accounting and auditing profession worldwide and it can be seen as one of the most important regulatory changes in accounting and financial reporting history. Over 100 countries have moved towards reporting in accordance with IFRSs and regulators expect an increase of the comparability of financial statements, an increase of transparency and an improvement of the quality of financial reporting. In this regard, broad literature is focused on the effects of the IFRSs in different aspects of the business environment and the economy as a whole.

Strengthening the financial reporting regime, as a result of financial crises, has led to a stronger oversight of the accounting and auditing profession as well. As such, in the future, this would prevent a similar crisis by distributing and eliminating the risks. Consequently, the adoption of IFRSs is well supported by many countries because it can improve the quality, timeliness and international comparability of financial reporting systems by creating a common financial reporting language.

Moreover, these objectives cannot be achieved without a proper monitoring and supervision from the regulators, who seek to promote the rigorous and consistent use of IFRSs.

Another issue that seems to come into view is that, based on research, the adoption of IFRSs improves the information environment and reduces the information asymmetry, thus affecting the capital market and resulting in a reduction of cost of capital.

In general, the literature review suggests that the application of IFRSs leads to an increase in the quantity and / or quality of specific financial information of companies and more disclosures in the financial information for public use. This leads to the fact that the adoption of IFRSs is associated with lower flexibility in accounting and lower analyst forecast errors (Ashbaugh and Pincus, 2001), lower costs of capital and loan interest rates (Leas and Verrechhia, 2000), higher performance coefficients (Bartov et al., 2005), higher performance ratios (Daske et al., 2007; Kim and Shi, 2009a), higher market liquidity and higher trading volume, better accounting quality and financial reporting (Barth et al., 2008), increased investment as a result of attracting more foreign funds and greater efficiency in contracting private debt (Covrig et al, 2007; Kim et al., 2010).

In our study we have chosen to analyze the impact of IFRS adoption on loan terms for companies in Kosovo, since there is no capital market in Kosovo, and financing of the companies, even mandatory IFRS adopters, relies mostly on bank loans.

Therefore, the aim of this study is to give an empiric answer to the research question of whether adoption of IFRSs in a developing economy of Kosovo has had a significant impact on loan terms and cost of borrowing capital or not.

Although Kosovo has adopted IFRSs since 2012, no such research has been done in this area, neither on other benefits or costs of implementing these standards. In fact, some previous studies have documented the differential effects of IFRSs on capital markets and the information environment across different countries. For example, Daske et al. (2008) found that capital markets that benefit from IFRSs exist only in countries with strong enforcement; Byard et al. (2011) noted that the adoption of IFRSs only improves the information environment of analysts in countries with both robust enforcement regimes and accounting standards that differ significantly from the IFRS; Landsman et al. (2012) commented that the improvement in the content of financial information after the adoption of IFRSs is greater in countries with strong legal enforcement. DeFond et al. (2011) and Yu (2012) indicated that the adoption of IFRS hampers greater cross-border investments.

Overall, the literature shows that the adoption of IFRSs has significant implications on markets, information asymmetry, cost of capital, on increasing the reliance and trust on financial statements information, transparency and accountability and in developing the economy as a whole.

We find that most of the research argues that companies in countries that apply IFRSs and IASs have higher quality of accounting and financial reporting, evidenced and documented by stronger recognition and measurement policies for transactions and accounts in financial statements, such as a "fair value" concept in accounting, as a major feature of IFRSs.

Compared to local accounting standards, IFRSs have broader disclosure requirements and accounting rules, which will impact on better serving the needs of 
"interested" parties such as investors, creditors, oversight authorities, etc. in decisions' process, with timely and relevant information. In this regard, we noted that in most of the literature this comparison between local and international standards comes as a result of IFRSs having detailed rule basis for measuring and recognizing assets and liabilities, expenses and revenues, equity elements, employee benefits, as well as extensive disclosure requirements for transactions with related parties, information about subsidiaries, cash flow statement, etc. In fact, in local accounting and financial reporting standards the above mentioned requirements may often be simplified or lack at all.

Some studies show that the economic consequences of IFRSs are also explained and justified by changes in the financial reporting and auditing environment, the level of enforcement of laws and regulations, the level of capacity building for the implementation of IFRSs, adoption and implementation of audit standards etc. (Hail et al., 2010).

Further on, previous studies generally document a positive effect of adoption of IFRS in the environment of financial analysts and capital markets (e.g. Landsman et al., 2011; Byard, Li, and Yu, 2011; Tan, Wang, and Welker, 2011). However, findings show that the effects of adoption of IFRS in capital markets are partly attributable to improved voluntary disclosures, as this has a positive impact also on the information environment and liquidity (e.g. Welker, 1995; Leuz and Schrand, 2009; Balakrishnan et al., 2012). Specifically, the liquidity benefits from IFRSs are greater for firms that increase their level of voluntary disclosures and this suggests the existence of an indirect mechanism by which IFRSs affect the liquidity of companies.

On the other hand, Nobes and Parker (2006) point out that although the harmonization of accounting and financial reporting standards will raise many benefits, there are many elements to be considered in the harmonization of these standards such as culture, economic and political systems that are different not only between developed and developing countries, but also between countries that may have similar characteristics. These elements can be considered as barriers to adoption and harmonization process.

Haller and Walton (2003) show that standardization is the way of using single accounting rules, while harmonization is the way of reducing the differences between accounting systems that will help improve the comparability of financial results in different countries (Radebaugh et al., 2006). Harmonization of accounting and financial reporting standards is motivated by many factors such as the growth of foreign direct investment (FDI), the growth of financial markets and the development of multinational organizations (Gray, 1988).

\section{Literature review}

When analyzing the literature on "pros and cons" of the IFRS adoption, we find that while mandatory IFRS implementation is a part of the countries' reporting framework and financial reporting regime, with the aim to increase the quality of financial statements in benefit of transparency, accountability and comparability for all the stakeholders in order to protect the public interest, voluntary adoption of IFRSs can be incentivized by a strategic commitment of a firm to provide better financial reporting strategies and higher level of disclosure of financial information (Leuz and Verrecchia, 2000; Covrig et al., 2007).

Largely, firms usually make decisions to switch their financial reporting standards as in some of the three cases below:

- First, when adopting a new set of standards, a voluntary change gives firms the opportunity to choose between two possibilities: one is based on management expectations to get a lower capital cost, resulting from high quality information and a lower information asymmetry, and the other one resulting in a higher market evaluation of a firm (Leuz and Verrecchia, 2000). In this regard, for voluntary adopters usually the benefits outweigh the convergence and transition costs for the fast-growing internationally owned companies (Harris and Muller, 1999).

- Secondly, flexible mandatory transition to IFRS gives opportunities to firms to decide over the time of change. Balsam et al. (1995) find that companies in these cases attempt to postpone the time for transition to IFRSs, so "reported earnings increase and corporate debt constraints decrease."

- Finally, mandatory changes dictate both the new standards and the transition time to IFRSs.

The effectiveness of the regulation in achieving such benefits as a reduction in the cost of capital is likely to depend on the degree to which the institutional 
environment (e.g., the quality of legal enforcement) motivate the financial statements preparers (e.g., Ball et al., 2003).

Therefore, it is still unclear how the cost of capital is affected by the adoption of IFRSs and this remains an empirical question.

In fact, the empirical results in academic literature so far are mixed. Mostly based on the significances for capital markets, existing literature highlights a considerable heterogeneity in the economic consequences of the adoption of IFRSs.

Extending disclosures through the voluntary adoption of IFRSs may affect market participants' incentives for gathering, processing and disseminating specific information of the company. However, the abovementioned studies in general do not provide a clear answer to the question of whether additional disclosures under IFRSs encourage or discourage the involvement of specific company information, reflecting not only the cost of capital but also stock prices.

On the other hand, increasing the quantity and quality of public information in compliance with IFRSs may reduce the cost and increase effectiveness of obtaining specific information about the company and thus discourage market participants from collecting and disseminating private information, as more comprehensive information is made publicly available (Kim and Verrecchia, 2001). In such a case, stock prices and cost of capital move along with public information (Dasgupta et al., 2010). Given the lack of evidence on which of these effects dominate, the objective of these studies is to test whether and how the voluntary adoption of IFRSs improves the impact of specific company information on stock prices, thus reducing the cost of capital.

Easley and O'Hara (2004) as well as Leuz and Verrecchia (2004) predict that firms with higher risk of information will have higher cost of capital. The risk of information is related to the uncertainty or impreciseness of information used or needed and desired by investors, and the latter necessarily relates to the price of securities. In addition to creating a common reporting language, adoption and implementation of the IFRS is assumed that will also eliminate the above-mentioned risk.

Previous research also suggests an indirect link between disclosures and cost of capital of firms, based on market liquidity and adverse selection in secondary markets (e.g., Diamond and Verrecchia, 1991; Baiman and Verrecchia, 1996; Easley and O'Hara, 2004).

However, these studies, analyze the parameters with a single company (or parameters where the cash flows in all firms are unrelated). Thus, it is unclear whether the effects shown in these studies are persistent to the diversification and expand into more general parameters. Piotroski (2005) finds that the increase of the disclosure is positively correlated with analysts' forecasts and profit capitalization rates, but this study does not document significant changes in the liquidity of the companies which have been part of this study.

Although some studies (e.g., Ball, 2001; Ball et al, 2003) have an uncertainty on the effect of adopting international financial reporting standards at the local level without institutional support, recent studies argue that the decision of a company to voluntarily apply IFRSs leads to preferred economic consequences and the evidence shows that IFRS disclosures are, on average, of higher quality than those that are in compliance with local accounting and financial reporting standards in the majority of financial reporting regimes.

These studies are consistent with Aboody et al. (2004) and Easley and O'Hara (2004), which provide evidence that the risk of information is costly and thus it's perceived that a cost reduction can result in a market reaction. Investors may also react positively to adoption of IFRSs if they expect the implementation to have positive effects on the cash flow. The improvement of future liquidity for firms is as a result of a greater disclosure and this lowers the firm's cost of capital.

\section{2. scientific research}

\subsection{Methodology}

In this research, we have scientifically analyzed the results to test our hypothesis based on the statistical methods such as: descriptive statistics, ANOVA variances analysis, the standard deviation and the statistical $F$ test.

The research data consist in primary and secondary data, where primary data are collected from questionnaire responses and interviews with banks and companies that are mandatory adopters of IFRSs and 
secondary data are collected from other similar studies, guides and IFRSs, as issued by the International Accounting Standards Board (IASB). The questionnaire for primary data was designed for banks and the other one for secondary data was designed for companies, consisting of 2 parts. The first part included questions for determining the characteristics of respondents and the second part included questions regarding respondents' opinion on each of the loan terms that can be impacted by the adoption of IFRSs.

Respondents were asked if the companies that prepared their financial statements in accordance with IFRSs benefit from lower interest rates on loans, which were measured using Likert scale from 1 to 5 (1-Strongly disagree, 2-Disagree, 3-Neutral, 4-Agree and 5-Fully agree).

Respondents were further asked to calculate the level of compliance with the various assertions in the questionnaire. Each response's rank (1 to 5) was multiplied by the weight (1 to 5), where the highest level of compliance gets the most weight.

Respondents were also required to assess if companies that prepare IFRS financial statements benefit from other loan terms such as time limits, mortgages, lower administrative costs, and so on. Moreover, respondents were asked if banks make possible renegotiations on loan terms and whether the percentage of bad loans for companies reporting under IFRSs is lower compared to other firms.

\subsection{Hypotheses}

Based on both prior research and the literature review, we have developed our hypotheses as presented below:

$\mathrm{H} 1$ : Adoption of IFRSs in Kosovo has impact on interest rates offered by banks to mandatory adopters;

H2: Adoption of IFRSs in Kosovo has impact on nonfinancial loan terms such as: time limits, mortgages, lower administrative costs and renegotiating loan terms;

H3: Mandatory IFRS adopters have a better loan rating compared to other companies in Kosovo;

$\mathrm{H} 4$ : The percentage of bad loans / debts (nonperforming loans) is lower for mandatory IFRS adopters in Kosovo.

\subsection{Sample}

The population of this research is comprised of all the banks in Kosovo and the mandatory IFRS adopters in Kosovo.

The total number of banks in Kosovo is 10; we have collected responses from 56 loan analysts in 9 banks ( $90 \%$ of the population), those that analyze financial statements prepared under IFRSs and have an impact on loan decision making.

In the private sector in Kosovo there are $\mathbf{2 5 2}$ mandatory adopters; we have collected responses from 182 companies (a sample of $72 \%$ of the population). Referring to the complexity and constraints encountered in the sample selection from such a large population of companies adopting IFRSs in Kosovo, random sample selection was used in our research.

\section{Research results}

\subsection{Demographic characteristics of respondents}

As mentioned above, first part of the questionnaire was designed to get an overview of respondent's characteristics. Based on the results (as shown in Table no. 1) from the banking sector, a vast majority have master degree $(55.88 \%$, representing a number of 31 respondents), $44.12 \%$ of the respondents ( 25 respondents) have a bachelor degree and none of them has a Ph.D. degree. Regarding their professional qualification, $64.52 \%$ of the respondents (a number of 36 respondents) are Accounting Technicians, $29.03 \%$ of the respondents (a number of 16 respondents) are Certified Accountants, 6.45\% of them (a number of 4 respondents) are Certified Auditors, and none of them is a Statutory Auditor (practicing auditor). Since the law in Kosovo for statutory auditors requires candidates to be working in practice as auditors, and the respondents from banks were not working as auditors, this is the reason why this is zero. With regard to their experience in the banking sector, $50 \%$ ( 28 respondents) had $5-10$ years of experience, $23.53 \%$ (13 respondents) had $10-15$ years of experience and $5.88 \%$ ( 3 of respondents) had more than 15 years of experience. 


\section{Table no. 1. Education, professional background and experience of respondents from banking sector}

\begin{tabular}{|l|l|c|c|}
\hline \multicolumn{1}{|c|}{ Variable } & \multicolumn{1}{|c|}{ Categories of variable } & Frequency & Percentage \\
\hline Academic degree & Bachelor & 25 & $44.12 \%$ \\
& Master & 31 & $55.88 \%$ \\
& Ph.D. & 0 & $0 \%$ \\
\hline Professional & Certified accounting technician & 36 & $64.52 \%$ \\
degree & Certified Accountant & 16 & $29.03 \%$ \\
& Certified Auditor & 4 & $6.45 \%$ \\
& Statutory Auditor & 0 & $0 \%$ \\
\hline Experience in & Less than 5 yrs. & 12 & $20.59 \%$ \\
banking sector & 5-10 yrs. & 28 & $50.00 \%$ \\
& $10-15$ yrs. & 13 & $23.53 \%$ \\
& More than 15 yrs. & 3 & $5.88 \%$ \\
\hline
\end{tabular}

Source: Authors' projection

Since in our study we have also taken into consideration opinions from private sector, respectively those companies that are mandatory adopters of IFRS in Kosovo, we have shown the characteristics of respondents from this sector as well (as disclosed in Table no. 2). In this regard, from the private sector $63.54 \%$ or 116 have academic degree as Master, $31.25 \%$ or 57 have Bachelor Degree and $5.21 \%$ or 9 have Ph.D. degree. For professional qualification $37.5 \%$ or 68 of respondents are Certified Accountants, $28.13 \%$ or 51 are Certified Accounting Technicians, $27.08 \%$ or 49 are Certified Auditors and $7.29 \%$ or 14 are Statutory Auditors. Regarding their experience, $31.95 \%$ or 58 respondents have $5-10$ years of practical experience, $28.86 \%$ or 53 have $10-15$ years, $21.67 \%$ or 39 have more than 15 years of experience and $17.52 \%$ or 32 have less than 5 years of experience.

\section{Table no. 2. Education, professional background and experience of respondents from private sector}

\begin{tabular}{|l|l|c|c|}
\hline \multicolumn{1}{|c|}{ Variable } & Categories of variable & Frequency & Percentage \\
\hline Academic degree & Bachelor & 57 & $31.25 \%$ \\
& Master & 116 & $63.54 \%$ \\
& Ph. D. & 9 & $5.21 \%$ \\
\hline Professional & Certified accounting technician & 51 & $28.13 \%$ \\
degree & Certified Accountant & 68 & $37.50 \%$ \\
& Certified Auditor & 49 & $27.08 \%$ \\
& Statutory Auditor & 14 & $7.29 \%$ \\
\hline Experience in & Less than 5 yrs. & 32 & $17.52 \%$ \\
company & $5-10$ yrs. & 58 & $31.95 \%$ \\
& 10-15 yrs. & 53 & $28.86 \%$ \\
& More than 15 yrs. & 39 & $21.67 \%$ \\
\hline
\end{tabular}

Source: Authors' projection

Based on these results, it is seen that the respondent's level of understanding of these international reporting standards is quite satisfactory, given their academic, professional qualifications, as well as the work experience in accounting, finance or auditing. As such, the received answers can be considered very relevant and important to test the research hypotheses.

\subsection{Testing the hypothesis and research results}

The variance analysis results (ANOVA) show that there was a significant variation in the impact of the IFRS on borrowing terms for companies applying IFRSs from the perspective of a banking sector, with a variance 
$F=7,004$ and significance $p<0.01$. Apart from analyzing whether the interest rates will be lower or not for these companies, we have also empirically proved that there is a significant impact on the other non-financial terms of the loans, as well as those presented in Table no. 3.

The analysis shows that the impact of adopting IFRSs is greater in the credit rating (average value 4.34, standard deviation 0.63), which indicates that the companies whose statements are prepared under IFRS have the best credit ratings for banks in Kosovo, compared to those that do not prepare the financial statements in accordance with these standards. Based on the results in Table no. 3, the second component influenced by the use of IFRSs is the loan time limits (average value 4.11, standard deviation 0.94), third component is mortgage requirements (average value 4.08 , standard deviation 0.91), fourth component is interest rates (average value 4.02, standard deviation 0.82 ), consisting in the adoption of IFRSs at lower interest rates. The fifth component shows that companies using IFRSs have the low percentage of non-performing loans (average value 3.94, standard deviation 0.89), the other component affected by IFRSs is the renegotiation of loan terms (the average value 3.83 , standard deviation 0.97 ) and the last component rated by respondents are the administrative costs (average value 3.52 , standard deviation 0.92 ).

\section{Table no. 3. Results of ANOVA analysis on the impact of adoption of IFRSs on loan terms from the perspective of the banking sector}

\begin{tabular}{|l|c|c|c|c|}
\multicolumn{1}{|c|}{ Variables } & Average & $\begin{array}{c}\text { Standard } \\
\text { deviation }\end{array}$ & F & Pr $>F^{*}$ \\
\hline Interest rate & 4.02 & 0.82 & 7.004 & 0.008 \\
\hline Loan time limits & 4.11 & 0.94 & & \\
\hline Mortgage requirements & 4.08 & 0.91 & & \\
\hline Lower administrative cost & 3.52 & 0.92 & & \\
\hline Renegotiation of loan terms & 3.83 & 0.97 & & \\
\hline Better credit rating & 4.34 & 0.63 & & \\
\hline Lower percentage of non-performing loans & 3.94 & 0.89 & & \\
\hline
\end{tabular}

*significant $p<0.05$

Source: Authors calculations from the questionnaire data

To test the hypothesis of our study and since the questionnaire was sent to companies that adopt IFRSs in order to have a full view of the situation on both sides, we have also presented the data analysis from the questionnaire sent to companies (shown in Table 4). According to the data from the analysis in Table 4, we see that the results from the ANOVA analysis are the variance ratio $\mathrm{F}=$ 25.348 and significance $p<0.01$.

According to these results, the private sector, therefore, companies surveyed for the impact of IFRSs on credit terms, have estimated that the term which is influenced the most by the adoption of IFRSs in Kosovo is the credit rating, which is also in line with responses received from the banking sector (average value 4.20, standard deviation 0.98). The second component influenced by the use of IFRSs is represented by the mortgage requirements (average value 4.03 , standard deviation 0.86 ), followed by loan time limits (average value 3.83, standard deviation 1.13), the other component affected by IFRSs is the renegotiation of loan terms (average value 3.81 , standard deviation 1.12), then interest rates (average value 3.80, standard deviation 1.13), lower administrative costs (average value 3.64, standard deviation 0.85) and the latest component rated by companies is considered the lowest percentage of non-performing loans (average value 3.60 , standard deviation 1.04). 


Table no. 4. Results of ANOVA analysis on the impact of adoption of IFRSs on loan terms from a perspective
of private sector
\begin{tabular}{l|c|c|c|c|} 
Variables & Average & $\begin{array}{c}\text { Standard } \\
\text { deviation }\end{array}$ & F & $\operatorname{Pr}>F^{*}$ \\
\hline Interest rate & 3.80 & 1.13 & 25.348 & $<0.0001$ \\
\hline Loan time limits & 3.83 & 1.13 & & \\
\hline Mortgage requirements & 4.03 & 0.86 & & \\
\hline Lower administrative cost & 3.81 & 1.12 & & \\
\hline Renegotiation of loan terms & 3.64 & 0.85 & & \\
\hline Better credit rating & 4.20 & 0.98 & & \\
\hline Lower percentage of non-performing loans & 3.60 & 1.04 & & \\
\hline
\end{tabular}

*significant $p<0.05$

Source: Authors calculations from the questionnaire data

Based on the results presented above, we see that there was a significant variation in the impact of the IFRS on loan terms for companies applying IFRSs in Kosovo from both the perspective of a banking sector and private sector, therefore we accept as scientifically proven all the above-mentioned hypothesis.

\section{Bonclusion}

In our study having significant results from ANOVA analysis from both banking and private sector, we have concluded that the adoption of IFRSs in Kosovo had an impact on interest rates, offered by banks to mandatory adopters and as well on non-financial loan terms such as: time limits, mortgages, lower administrative costs, and renegotiating loan terms. Mandatory IFRS adopters have a better loan rating compared to other companies in Kosovo and the percentage of non-performing loans is lower for mandatory IFRS adopters in Kosovo.

Literature review brings to our attention that in order to have a more reliable, comprehensive and transparent information available for all stakeholders including banks, only adopting IFRSs as a reporting framework of a country is not enough. If IFRSs are not applied consistently and if firms have no incentives to improve their financial reporting systems, the benefits of adoption will not be visible.
Therefore, based on the above research, our suggestion to policy makers, especially those in developing and transitional countries, is that only the implementation of high quality financial reporting standards, such as IFRSs, is not sufficient to improve the quality of accounting and financial reporting, while there are no institutional mechanisms that empower the implementation of IFRSs and while companies do not have the benefits and incentives that exceed the costs, to provide high-quality information to stakeholders.

Future area of research can consist in a larger number of companies in Kosovo, analyzing the benefits of IFRS adoption not only from one dimension - respectively from the perspective of loan terms - but also focused on analyzing costs and benefits of the adoption of IFRSs in Kosovo. Given the fact that Kosovo is in a development process and has lately adopted IFRSs, there are no research studies that have been conducted in this area until now.

Other future research recommendation can refer to including a comparison with other Eastern European countries, especially those that have similarities with Kosovo's economy, and to analyze the differences and similarities, the challenges and opportunities on the adoption of IFRSs, in a comparative manner with these countries. 


\section{REFERENCES}

1. Aboody, D., E. Barth, M. \& Kasznik, R. (2004). Firms' voluntary recognition of stock-based compensation expense. Journal of Accounting Research, 42(2), 123-150.

2. Aisbitt, S. \&Nobes, C. (2001). The true and fair view requirement in recent national implementations. Accounting and Business Research, 31(2), 83-90.

3. Armstrong, C., M. Barth, A. Jagolinzer, and E. Riedl. (2008). Market reaction to the adoption of IFRS in Europe. The Accounting Review

4. Bailey, D. (1995). Accounting in transition in the transitional economy. European Accounting Review, 4(4), 595-623.

5. Baiman, S., \& Verrecchia, R. E. (1996). The relation among capital markets, financial disclosure, production efficiency, and insider trading. Journal of accounting research, 1-22.

6. Baker, C. R., Mikol, A., \& Quick, R. (2001). The future of the accountancy profession in Europe, Part II. European Accounting Review, 10(4), 763-786.

7. Ball, R. (2006). International Financial Reporting Standards (IFRS): pros and cons for investors. Accounting and business research, 36(sup1), 5-27.

8. Byard, D., Li, Y., \& Yu, Y. (2011). The effect of mandatory IFRS adoption on financial analysts' information environment. Journal of accounting research, 49(1), 69-96.

9. Covrig, V. M., Defond, M. L., \& Hung, M. (2007). Home bias, foreign mutual fund holdings, and the voluntary adoption of international accounting standards. Journal of Accounting Research, 45(1), 41-70.

10. Dasgupta, S., Gan, J., Gao, N., (2010). Transparency, price informativeness, and stock return synchronicity: Theory and evidence. Journal of Financial and Quantitative Analysis 45, 11891220.

11. Daske, H., Hail, L., Leuz, C., Verdi, R., (2008). Mandatory IFRS reporting around the world: Early evidence on the economic consequences. Journal of Accounting Research 46, 1085-1142.
12. DeFond, M., Hu, X., Hung, M., \& Li, S. (2011). The impact of mandatory IFRS adoption on foreign mutual fund ownership: The role of comparability. Journal of Accounting and Economics, 51(3), 240-258.

13. Diamond, D. W., \& Verrecchia, R. E. (1991). Disclosure, liquidity, and the cost of capital. The journal of Finance, 46(4), 1325-1359.

14. Easley, D., \& O'Hara, M. (2004). Information and the cost of capital. The journal of finance, 59(4), 1553-1583.

15. Garrod, N., \& Turk, I. (1995). The development of accounting regulation in Slovenia. European Accounting Review, 4(4), 749-764.

16. Gernon, H., \& Wallace, R. O. (1995). International accounting research: A review of its ecology, contending theories and methodologies. Journal of Accounting literature, 14, 54.

17. Gray, S. J. (1988). Towards a theory of cultural influence on the development of accounting systems internationally. Abacus, 24(1), 1-15.

18. Haggard, K.S., Martin, X., Pereira, R., (2008). Does voluntary disclosure improve stock price informativeness? Financial Management 37, 747-768.

19. Holthausen, R.W., (2009). Accounting standards, financial reporting outcomes, and enforcement. Journal of Accounting Research 47, 447-458

20. Hail, L., Leuz, C., \& Wysocki, P. (2010). Global accounting convergence and the potential adoption of IFRS by the US (Part I): Conceptual underpinnings and economic analysis. Accounting Horizons, 24(3), 355-394.

21. Harding, F. (2000). What is the role of Europe in an increasingly harmonized world? European Accounting Review, 9(4), 593-601.

22. King, N., Beattie, A., Cristescu, A. M., \&Weetman, P. (2001). Developing accounting and audit in a transition economy: the Romanian experience. European Accounting Review, 10(1), 149-171.

23. Land, J., \& Lang, M. H. (2002). Empirical evidence on the evolution of international earnings. The accounting review, 77(s-1), 115-133. 
24. Landsman, W. R., Maydew, E. L., \& Thornock, J. R. (2012). The information content of annual earnings announcements and mandatory adoption of IFRS. Journal of Accounting and Economics, 53(1-2), 34-54.

25. Leuz, C., 2003. IAS versus U.S. GAAP: Information asymmetry-based evidence from Germany's new market. Journal of Accounting Research 41, 445-472.

26. Leuz, C., Nanda, D., Wysocki, P.D., 2003. Earnings management and investor protection: An international comparison. Journal of Financial Economics 69, 505-527.

27. Leuz, C., Verrecchia, R.E., 2000. The economic consequences of increased disclosure. Journal of Accounting Research 38, 91-124.

28. Li, S. (2010). Does mandatory adoption of International Financial Reporting Standards in the European Union reduce the cost of equity capital? The accounting review, 85(2), 607-636.

29. Nobes, C. W. (1992). Accounting Comparisons: UK. Europe, 3.

30. Nobes, C., Parker, R. B., \& Parker, R. H. (2008). Comparative international accounting. Pearson Education.

31. Piotroski, J. D., \& Roulstone, D. T. (2005). Do insider trades reflect both contrarian beliefs and superior knowledge about future cash flow realizations? Journal of Accounting and Economics, 39(1), 55-81.
32. Plaats, E. V. D. (2000). Regulating auditor independence. European Accounting Review, 9(4), 625-638.

33. Radebaugh, L. H., Gray, S. J., \& Black, E. L. (2006). International accounting and multinational enterprises. New York, NY: John Wiley \& Sons.

34. Saudagaran, S. M., \& Meek, G. K. (1997). A review of research on the relationship between international capital markets and financial reporting by multinational firms. Journal of Accounting Literature, 16, 127.

35. Silva, F. J. F., do Couto, G. M. M., \& Cordeiro, R. M. (2009). Measuring the impact of International Financial Reporting Standards (IFRS) to financial information of Portuguese companies. Revista Universo Contábil, 5(1), 129-144.

36. Sucher, P., \& Jindrichovska, I. (2004). Implementing IFRS: A case study of the Czech Republic. Accounting in Europe, 1(1), 109-141.

37. Van Hulle, K. (2004). From accounting directives to international accounting standards. The economics and politics of accounting: international perspectives on research trends, policy, and practice, 349-75.

38. Walton, P., Haller, A., \& Raffournier, B. (Eds.). (2003). International accounting. Cengage Learning EMEA.

39. West, B. P. (2003). Professionalism and accounting rules (p. 8). London: Routledge. 